\title{
Aldose Reductase Inhibitor
}

National Cancer Institute

\section{Source}

National Cancer Institute. Aldose Reductase Inhibitor. NCI Thesaurus. Code C72880.

Any substance that inhibits aldehyde reductase (aldose reductase), an enzyme that

participates in glucose metabolism and osmoregulation. Aldehyde reductase has been implicated in inflammatory disorders and diabetic complications. 